\title{
Just an ordinary Jew
}

\section{A case for why Paul should be studied within Jewish studies}

\author{
Stefan LARSSON
}

Aвstract - The apostle Paul, author of many letters in the New Testament, is often considered to be the father of Christian antisemitism and a staunch opponent of keeping the Torah. This perspective has been shared both by Jews and Christians throughout the centuries, until the late twentieth century. For the last forty years or so, a new paradigm on Paul has taken shape, one where Jewish scholarship and research on ancient Judaism is making a significant difference. The picture of a Second Temple-period Pharisee is emerging, possibly with connections to early forms of Merkabah mysticism. There are no longer any reasons but 'tradition' that Paul should not be a part of Jewish studies, and this article gives some of the arguments for this timely re-appropriation of one of the best-known Jews in history.

Why is Paul of the New Testament studied only within theology, and not also within Jerwish studies? The question perhaps seems trivial to many - Paul was a Christian, his texts are preserved in the Christian collection of texts known as the New Testament, and his writings contain several passages which renounce the Jewish law and way of life. Both in Christian and Jewish camps of religious studies, no-one particularly wants Paul to move across the border between the two. In the Church history camp, he is a theological giant; in the Jewish camp he is the father of Christian antisemitism. Yet new bold moves have been made in Pauline studies over the last fifty years that have come to reveal a Paul much more at home in ancient Judaism than was ever previously envisaged. It seems that both camps have their positions locked down, owing to theological tradition rather than to historical-critical research. In this article I would like to plea for a reassessment: primarily within Jewish studies to bring Paul onboard, but also secondarily amongst New Testament scholars to change their mind, should they harbour any resistance towards 'sharing Paul with Judaism'.
The matter all hinges on a didactic issue: according to the traditional Christian interpretation, what Paul meant to convey in his teachings was the knowledge of how the life, death and resurrection of Jesus the Messiah necessitated an exit (without return) from the legalistic, socially isolating Jewish practice of the 'old testament' commandments. Instead, people were to enter into the 'new' law-free, Spirit-filled, non-ethnocentric spirituality of Christianity. And still, what Paul seems to have been doing, as he penned letters to his congregations, was to repeatedly tell the non-Jewish readership to back off from things deemed Jewish. Paul's teachings did not hit home. The letter to the Galatians was, from this standard perspective, supposed to remedy Paul's failed preaching efforts by critiquing the Galatians' infatuation with the law and circumcision. But could it really have been that hard to drive the point home to the Galatians that the synagogue, the Torah and the Jews as a nation were off limits and no longer had any central place in God's religion? If we adhere to the traditional theological understanding of Paul as a 'convert' to 'Christianity', that is, something 
diametrically opposed to Judaism, then we must conclude that Paul's disciples were either quite dim, or that Paul was not such a great teacher after all - or both.

Over the last forty years or so another perspective on Paul the Christian theologian has seen the light of day, albeit still emerging and taking form through the input of a growing number of scholars. This new paradigm has sometimes been called the radical perspective, in view of its all but total rejection of the traditional tenets about Paul. Yet a better term, more popular of late, is the designation the Paul within Judaism perspective. ${ }^{1}$ And this is where the heading of this article comes in. Post-Holocaust studies and reflections on Paul have shifted the focus from him being a Lutheran 'No Torah here, please, and particularly no Jewish holidays!' kind of a thinker, to a Torah-loving, Pharisaic, midrashim-writing, halakhically explicating teacher; a Jew who himself remained within the authoritative and ideological boundaries of the synagogue culture (even to the extent of receiving punishments, although we are not quite sure for what), and who harboured a passionate love for his Jewish people and expectations of their total and final redemption, as a result of the covenantal faithfulness of the God of Israel. There is nothing un-Jewish about this Paul - and no reason why he should not be examined within Jewish studies.

\section{What took us so long?}

Why has this 'radical' shift in perception taken so long to emerge? We have been delving deep into Paul's writings for nearly two millennia if it's old it might not be gold, but if it's new, can it really be true? In this case, the concepts of cognitive dissonance and plausibility structure

1 For an overview of how scholars define this term, see for example Nanos and Zetterholm 2015 , and Eisenbaum 2009: esp. chs I 2 and I3. are relevant. Much has been invested in any one stance on the 'truth' about Paul, and changing one's mind means walking through the purging fires of reassessment - a particularly harsh ordeal when axioms of faith are shaken. Pauline scholars also too often find themselves in environments that reaffirm their basic over-all conclusions. Two cognitive factors thus play into this scenario.

\section{The filter of Christian theological traditions in exegesis}

Magnus Zetterholm has written in both his book Approaches to Paul (2009) and in the anthology Paul within Judaism (2015) about the influence of second century church theologians on the traditional view of Paul. The Adversos Ioudaeos literature from the early church period solidified a split between Judaism and Christianity, with horrifying outbursts of antisemitism in its wake, all the way up till modern times. Even if most Christian theologians today have renounced the antisemitic sentiments that previously existed, the notion is still deeply rooted that Paul could not possibly have been Jewish in any meaningful way. This 'filter', which Zetterholm refers to as the standard view on Paul, has had its exegetical heirs in modern times through particularly German theologians in the Tübingen and Bultmann schools (Zetterholm 2009: 33-94). It is difficult to become aware of and counter such filters when they constitute one's precepts.

2. The use of traditional terms and concepts in analyses of the Pauline texts

The words we use in translating and discussing Paul's letters define how we perceive his thoughtworld. 'Christian', 'Christianity' and 'church' are examples of terms which steer the interpretations towards their modern references, not towards the realities of the first century CE. Paul himself seems never to have known of any Christianity or people called Christians. Using such terminology hinders new insights into 


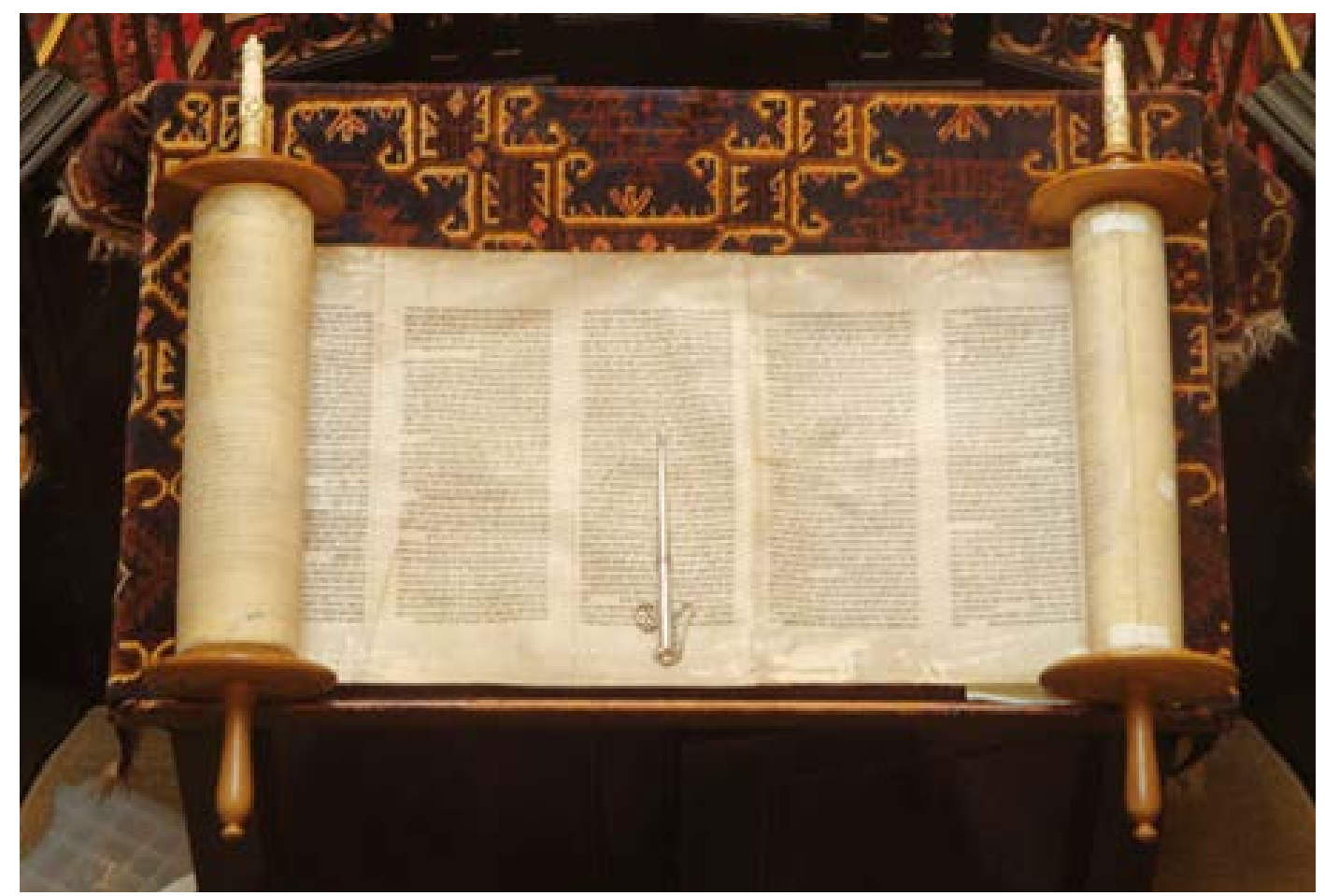

Open Torah scroll. Photo by Lawrie Cate, 2009, CC-BY-SA 2.0, Wikimedia Commons

the phenomena we study; we see only what we project, resulting in anachronistic conclusions. To prevent this from happening, we must 'de-familiarise' ourselves with the texts we study, by changing the terminology into something more neutral, and thus allow for our minds to 'de-colonise the past' (Runesson 2015: 55-6I).

These points relate to scholars with a traditional Christian bias. It is therefore interesting to note that the emergence of a Paul within Judaism perspective has arisen, largely through the efforts of Jewish readers of Paul. Rabbis and scholars in the late I80os and early I goos have helped to set the stage, for example the Reform rabbis Isaac Mayer Wise and Joseph Krauskopf, but also Claude Montefiore, and Leo Baeck in his later writings. There is also a growing group of Jewish scholars who, during the twentieth century and up to the present, have seen a Jewish and Torah-observant person in Paul; we might mention Hans Joachim Schoeps, Samuel
Sandmel, Pinchas Lapide, David Flusser, Alan Segal, Mark Nanos, Pamela Eisenbaum, Paula Fredriksen, and Tal Ilan as examples. ${ }^{2}$ Now, perhaps it is the case that Jewish scholars find a Jewish Paul, but many non-Jewish academics have been and are endeavouring to bring about this shift in perspective on Paul, for example William D. Davies, Johannes Munck, Krister Stendahl, John Gager, Lloyd Gaston, Stanley Stowers, William S. Campbell, Magnus Zetterholm, Caroline Johnson Hodge, Karin Hedner Zetterholm, Kathy Ehrensperger, Christine Hayes, Paul Duff, Anders Runesson, Brian Tucker, Neil Elliott, and Matthew Thiessen. These scholars, Jewish or not, would not all necessarily see themselves as a part of a Paul within Judaism

2 See Langton (2010: 77-96, I I 5-35) for a more comprehensive discussion of how these different scholars have contributed to debate about Paul within Judaism. 
paradigm, or at least not in the same way. They come to different conclusions on various points, but they have this in common, that they do see a Jewish Paul. Changing our beliefs about Paul thus has been a 'joint effort' by scholars coming from both Christian and Jewish thought milieux, and in the interest of future research on Paul this collaboration has to be fully democratised: the earliest decades of the Jesus-centred movement in Palestine have to be freed from exclusive Christian theological ownership and become as much the cultural and theological heirloom of Judaism as of Christianity.

\section{A look at some arguments for a Paul within Judaism reading}

But what are the main assertions from the Paul within Judaism perspective that call for such a revision? In the sections below, I will paint the broader strokes of some of the insights that studies of early Judaism have brought to our understanding of Paul and his Jewishness. The following pertains to Paul's view of: A. Judaism and the Jewish people; B. the gentiles; and C. the Torah. Where he is traditionally understood to have abandoned his Judaism to become an apostle to all people (Jews as well as gentiles) and considered the Torah to be a thing of the past, the arguments below will present the opposite a Paul dedicated to his Jewish faith and people, aiming specifically at the lost souls of the gentile nations, and yet still very much practising the Torah.

\section{A. Paul and Judaism}

\section{Second Temple Judaism(s) was/were not existential anguish}

In much traditional scholarship, Paul is believed to have left Judaism because of its many faults. According to the Torah-negative assessment of Paul, he thought that the law was cumbersome and enslaving for the Jews, and instead found freedom in Christianity. Since the r 970 s this polemical image of Judaism has been deconstructed and shown to be merely a creation of the church fathers, especially through the contributions of Krister Stendahl, the author of Paul among Jews and Gentiles, and E. P. Sanders, who wrote Paul and Palestinian Judaism, both ground-breaking books. Stendahl (I 976: I $3-$ I 4) contested the notion that Paul had been a guilt-ridden person struggling with the Torah, instead pointing to the passages where Paul describes his Jewish life and Torah-observance in positive terms. Sanders for his part has helped deconstruct the myth of the Hegelian clash between 'old bad Judaism' and 'new good Christianity'. He coined the term covenantal nomism for what he concluded to have been the overall dominating tenets of Second Temple Judaism, where Jews trusted in the faithfulness of God for their ultimate salvation from exile and earthly sufferings: and if they were to break God's commandments, then the temple cult existed to deal properly with sin (Sanders I 977: 422). The findings of these two scholars present a less existential and legalistic Judaism than that which Paul has traditionally been believed to criticise and leave behind. Jews did not believe that they had to keep all the laws unto perfection in order to have eternal life or God's blessings - the most important constituent was God's grace. ${ }^{3}$ Whatever Paul might have had an issue with in his letters, it was not the standard Jewish faith of his day.

Whereas Sanders still believed that Paul in the end left Judaism because 'it is not Christianity' (1977: 552), Mark Nanos is one of the first and most influential scholars to draw 'radical' conclusions from Sanders's insights. His books The Mystery of Romans (1996) and The Irony of Galatians (2002) were the first scholarly works to give a detailed account of how

3 See also Eisenbaum (2009: 88, 9I-2, 2 I 8, 246) for the discussion on Paul's Judaism. 
Paul's seemingly negative statements against the Torah and Jewish practices could be understood as intra-Jewish debates, and how Paul himself remained a Torah-practising Jew his whole life (Nanos r 996: 4, 9). The determining factor is context: whom Paul wrote to, why he wrote, and where Paul's congregations were situated. Nanos demonstrates that Paul was addressing, and sometimes aggressively attacking, certain ideas pertaining to the status of his gentile congregants, who seem to have been going through an identity crisis. They needed to be reassured that salvation through the Messiah indeed was for gentiles as well, not exclusively for Jews (Nanos 1996: 9, 2002: 2-4). Whereas the modern Christian question is 'Can one be Jewish and believe in Jesus?', the question Paul debated was rather 'Can one be gentile and believe in Jesus?' In giving his resounding 'yes' to the latter question, Paul's rhetoric has traditionally been interpreted as a rejection of Judaism, when what he really meant to clarify was the equal status of the gentile believers next to their Jewish brethren.

\section{Paul was called - not converted}

It is not only the larger cultural context of ancient Judaism that makes it difficult to construe Paul as a religious renegade: Paul's own writings seem to differ from such a conclusion. He never considered himself a non-Jew. He never claimed that he had left a faith-system behind, or 'repented' (Stendahl I976: 7-23; Eisenbaum 2009: I43, I 97). The verses sometimes used for such an interpretation of Paul are the letter to the Galatians I:I3-I4, where Paul mentions his 'previous way of life in Judaism'. But here the traditional translations run into trouble, since the term 'Ioudaismos' cannot be translated simply as 'Judaism'. Steve Mason (2007: 5 Ioff.) has argued that 'Ioudaismos' signified Judean law and life as an ethnic identity, not merely a belief system - to be a 'Jew' was to belong to the cultural matrix of a certain set of ancestral traditions, akin to the term 'citizen- ship' with connotations of belonging to Judaea or the land of Israel. Paula Fredriksen (2015: I78 and 20I7: 8-3I) and John Gager (2000: 24) further explicate how the modern notion of a meta-level, 'free-floating' religiosity disconnected from culture and ethnic identity is an anachronism. Conversion was not as 'simple' a matter as we often perceive it to be today, of shifting principles or dogmas in one's statement of faith - rather, it was nothing short of a total identity transformation. The 'middle ground' of the Christian religion did yet not exist. For Paul thus to have left Judaism would have put him in the 'pagan camp' of the non-Jews, rendering him an idolater - but his letters testify to his ongoing service to the one God of Israel, and to his self-identity as a Jew (Gager 2000: 24).

One final aspect validates this assumption: how Paul described the Jewish people as God's people. The Jewish nation had a particular and pivotal role to play in Paul's understanding of things - God had made a part (the majority, it seems) of Israel 'blind' to who the Messiah was, but when in due time they would be allowed to receive the revelation of Jesus (in some close future, Paul seems to have thought), it would result in resurrection of the dead and the ushering in of the Age to Come (Rom. I I: 15 ) (Nanos 2010: Iо, 25, 3I). Paul thus viewed the ethnic distinction between Jews and gentiles not only as relevant but as divinely ordained, for the progression of worldwide salvation. Nothing in his letters indicates that he viewed himself as some kind of anomaly in this scenario, who for some unknown reason had to leave his people and way of life behind, or who thought that other Jews should do so as well.

\section{The Jew was an ideal human being in Paul's congregations}

As mentioned previously, Paul apparently had to elevate and solidify the status of the non-Jewish Jesus-believers. To Mark Nanos (2002: 82) this implies that something in both the context where 
St Paul's statue in front of St Peter's Basilica (Vatican). Photo by AngMoKio, CC-BY-SA 2.5, Wikimedia Commons.

Paul taught (i.e. an environment that included Jews), as well as in the content of his teachings (i.e. Judaism was not off limits), gave non-Jews the impression that Jews were the norm, with a privileged identity (Nanos 201 5: I 34). When, for example, Paul in Gal. 3:28 juxtaposes various pairs, one of each pair has a 'preferred status': the free person over the slave, the male person over the female and the Jew over the gentile Greek (Eisenbaum 2000: 5 I 4). ${ }^{4}$ Paul himself expressed how the Jews were in a better position since they had 'the oracles of God' (Rom. 3:I-2) - they had access to the Torah (Nanos I 996: I 80). The way Paul described his Jewish identity (and sometimes that of his opponents) also reveals that the Jewish 'credentials' were signs of status in his congregations, not of something denigratory or negative. Even the Philippians 3 section, where Paul is traditionally often thought to discard his Jewish identity, could only function rhetorically if Jewish identity was something of great worth in his and in his readers' eyes (Nanos 2008; Eisenbaum 2009: I 40). If Paul had come with some kind of clear message of the end of Jewish Torah and way of life, then this is not the picture we would expect to emerge.

4 See also Kahn (201 I: 9-1 7) for an interesting discussion of the origins of a three-fold blessing within pre-rabbinic Judaism, to which Paul is most likely reacting, but with which his Galatian readers seem positively familiar. It is not impossible that they referred to this blessing as one of the arguments for their desired conversion, since it stated that God should be blessed for making a person Jewish, male and free.

\section{B. Paul and the gentiles}

\section{Paul addressed mainly and particularly gentiles}

The above three points suggest a positive Jewish spirituality and faith as part of Paul's identity, something which Paul and his congregants viewed as ideal. So why the passages in his letters where he seemingly devalued the Torah, the centrepiece of Jewish culture and life? The answer in short is Paul was an apostle to the gentiles. This had the natural but crucial consequence that Paul's letters were rhetorically addressed to (albeit of course not only read by) the non-Jews in his congregations (Gaston r 987: 5; Stowers I 994: 21; Nanos 2002: 77; Eisenbaum 2009: I 2, 2 I 6-I 7). His statements about the law were directed at gentiles practising or wanting to practise the law - not at Jews. Paul's rhetoric to these gentiles centred on explaining that they could not become Jews, and that they could not practise the Torah in any 'fuller' sense (Nanos 2015: I $34-5$ ), but that they were nevertheless equally saved and 'in Messiah' as Jesus-believing Jews were.

Why this particular mission to the nonJews of the nations outside Israel? Resurrection was envisioned by many Jews as something that would happen at the end of time - as would Judgement Day. Believing Jesus had 
been resurrected changed Paul's understanding of what time humanity was in - the pagans had to immediately abandon their idolatry, for God's wrath would soon be upon them otherwise (Eisenbaum 2009: I 49, I98-9, 219). This arrival of the end times, with its connotations for Paul, has been labelled the 'chronometric claim' by Nanos (201 5: 108-9). If there was anything out of the ordinary in Paul's descriptions of the Torah, it was motivated by this chronometric perspective. It was literally a matter of quickly rescuing as many lawless gentile souls as possible."

\section{Gentiles had to be saved as gentiles - not as Jews (that is, by 'works of the law')}

How come non-Jews were not allowed to convert, should they wish to do so? The Hebrew Bible's prophetic texts were divided on the issue of the gentiles - some texts indicated that they would be defeated and destroyed because of their idolatry and because of their oppression of Israel (Zetterholm 2003: 138); some texts expressed the vision of pagan nations turning to the God of Israel, coming to Jerusalem in what has been labelled the 'eschatological pilgrimage', and joining the Jews in worship (Fredriksen r99I: 544; Zetterholm 2003: I38). Paul subscribed to this latter vision - there was hope for the gentiles. One problematic point with this scenario, however, was that the nations should turn to God as gentiles, as representatives of all the peoples of the earth - not as converts, not as Jews. The prophecies spoke of a moral conversion amongst the nations, not a halakhic one (Fredriksen I 99 I: 547). God's plan was not for all of humanity to become Jews, but for all of humanity to recognise the one true God, the God of Israel (Nanos 2008: 30-5; Eisenbaum 2009: 96-8). In Romans I $5: 7-$ I $_{3}$, Paul quoted four biblical texts which all speak of how the gentiles praise God and how they should join with God's people in this praise. Once the kingdom of God had arrived, Jews and gentiles would eat together and worship together in Jerusalem, at the temple' (Fredriksen i 991: 548). For a Jesusbelieving gentile to adopt Jewish practices seems for Paul to have been a sign of unbelief regarding this future scenario, of not trusting God's promise to Abraham that the gentiles would be blessed by faith 'apart from law' (Eisenbaum 2009: I 70).

There is a specific reason for Paul's rigour on this point: in chapter I I of his letter to the Romans, he seems to indicate that the 'full number of gentiles' (i.e.from the seventy nations) had to come in, before all Israel (i.e. the twelve tribes) would be saved once and for all (Fredriksen 2015; Johnson Hodge 2007: I 52) (or as Mark Nanos puts it, before Israel would have the temporary protective 'callus' removed, which now covered and clouded their perception of Paul's ministry; Nanos 2010: 29-34). Waiting for the Messiah's second arrival thus constituted a kind of interim period where God demonstrated mercy towards the nations of the world by postponing his final vindication of Israel - it was by no means a rejection of the Jews. This is why the Sinai covenant was forbidden for non-Jews in this final phase of ushering in the Kingdom of God (Eisenbaum 2009: 102-3) - gentiles were not supposed to receive the eschatological grace of God through the Sinai covenant but through the new covenant promised by the prophets. In fact, there would have been nothing miraculous about gentiles converting to Judaism. The turning of the gentiles to the God of Israel and thus the 'reform of pagan worship' by the power of the Holy Spirit, on the other hand, was in Paul's eyes hard evidence that the Kingdom of God was at hand, when Israel would finally be saved from its sufferings and exile (Fredriksen 2015: I 97-201). 


\section{Paul and the Torah}

\section{The Torah-negative rhetoric:}

\section{'Jewish' Torah as 'no-no' for gentiles}

But even if Paul addressed mainly gentile readers in his letters, why the sometimes negative or depreciative statements about Torah? Could he not have chosen milder phrases to drive the point home, or simply have been more explicit about his views as presented in section 5 above? Turning gentiles as gentiles to the God of Israel demanded caution from Paul, so it seems: too positive a rhetoric towards things deemed Jewish would have encouraged some of his readers in the continued pursuit of conversion. Since his letters are contextual writings, we also cannot exclude the possibility that his readership was well-informed about his basic stance from previous letters and/or visits, and that he simply chose a hard line when trying to set things straight. For these purposes, having a mainly gentile, more thoroughly Hellenised readership demanded other types of tropes and arguments than if his readers had been Jewish. Being himself a diaspora Jew, Paul would have been well versed in rhetorical discourses about law in Graeco-Roman society, discourses known by many of his readers. Using such tropes from famous writings would have made it easier for Paul to get his message across: 'Remain gentiles - stay away from the Torah (at least in the way it was practised by Jews)'.

Christine Hayes (2015) suggests exactly this: she sees in Paul's lawverses traces of several existing discourses, from which Paul may have taken his cues. In Graeco-Roman texts, written law-code could, for example, be looked upon as a 'necessary evil' to combat bad inclinations, but which could never guide humans to true virtue; a law was lifeless letters that needed 'rescuing' by being embodied in a perfect being, who had to guide other humans in how to live accordingly; otherwise, sin and death stood in the way of human beings ever perfecting the observance of a law (Hayes 20 I $5: 54-89$, I 53-60). These and several other discourses, from the likes of Plato and Aristotle, would have allowed for Paul to more easily enter into known territory with his gentile readers, and, as it were, 'remind' them of common views of law. Such tropes served the purpose of allowing the gentiles to save face while at the same time being forcefully dissuaded from conversion and 'full' Torah-practice. Rather than denigrating the gentile readers, Paul chose to take the Torah down a few notches. Matthew Thiessen (2016) sides with Hayes on this hypothesis in his book Paul and the Gentile Problem, where he suggests that Paul actually viewed conversion as a violation of the Torah, since the Torah demands circumcision on the eight day after birth. To be a Jew, one had to be born into the Jewish people. Gentiles were of another 'seed'. If Thiessen is right on this assumption, there were thus both chronometric and genealogical reasons for Paul's teachings about the Torah.

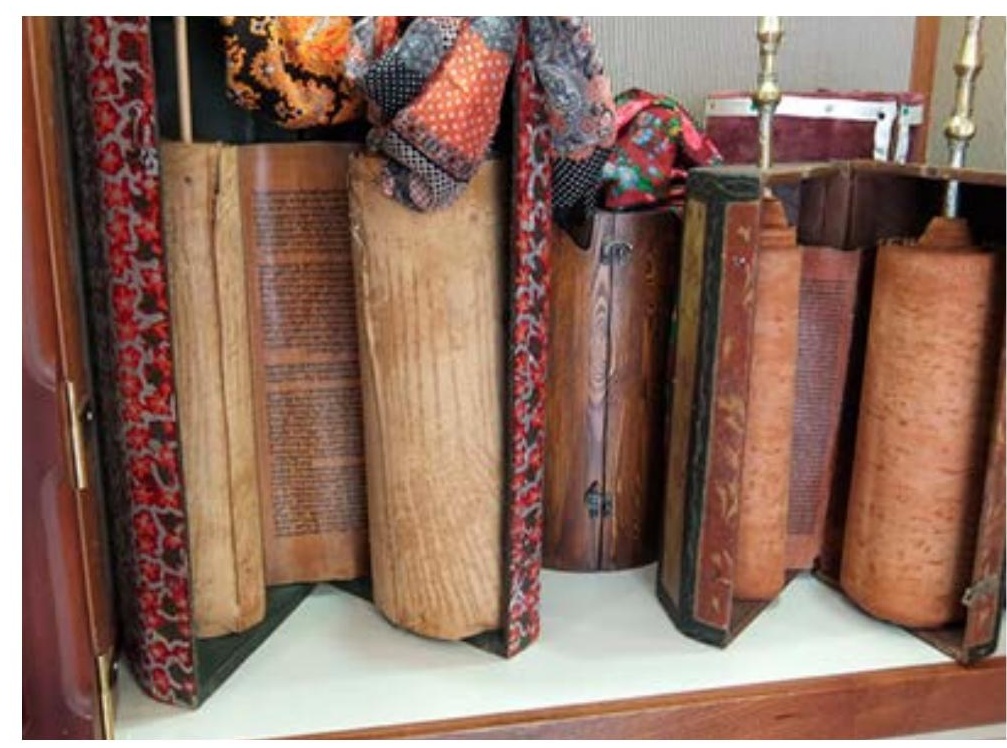

Yemenite Torah scrolls. Photo by Davidbena, 2018, CC-BY-SA 4.0. Wikimedia Commons. 


\section{Torah for gentiles:}

\section{purity, the Apostolic Decree and strict ethics}

Although the Torah might have been forbidden to non-Jews in some ways, Paul did teach a lot of Torah to his gentile congregants. It is a matter of definition. The discussion on Paul and the Torah so far has focused on what he prohibited for his gentile readership - conversion and change of ethnic identity - but at least as much could be said about what he actually did allow, or even demanded. Paul's letters testify to a comprehensive curriculum of ethical guidelines - actually, requirements - for a person's entry into the kingdom of God (cf. Gal. 5:2 I). One might even, according to Mark Nanos (1996: I79) and Magnus Zetterholm (2003: I 44-6), speak of a 'Torah for the gentiles'. Most likely this was based on a subset of rules, known as the 'Apostolic Decree' and presented in the Acts of the Apostles I 5 , to avoid: $a$. things sacrificed to idols; $b$. blood; $c$. things strangled; and $d$. fornication. These four rules were most probably extracted from Leviticus $17-\mathrm{r} 8$, regulating how 'the stranger within your gates', that is the nonJew amongst Jews, was to live within the Jewish society of Israel (Nanos I 996: 53). According to Nanos (ibid. 192-3), the reason why these laws were given in Acts I 5 was to secure a minimum of purity among gentile Christians who wanted to confess the Shema-formula of God's oneness and supremacy. The purpose of the Apostolic Decree was thus 'social purity', a minimum set of requirements that would allow for a halakhically acceptable mixing between Jews and gentiles - it had nothing to do with salvation through keeping the Torah (Nanos I 996: I 68n9, I 72-3).

The further issue of 'ethical' purity in Paul's congregations was also important and shines through in his letters. He expressed the notion that his gentile believers had holy bodies - that they were temples. His language concerning washing and purity is reminiscent of the temple cult in Jerusalem and priestly rules, and the gentile believers were accordingly to stay away particularly from idolatry and sexual immorality (Johnson Hodge 2015: I64ff.). Kathy Ehrensperger explicates on this point, showing how this notion of strict purity runs from the books of Leviticus and Ezekiel in the Hebrew Bible, through early Enochic traditions, to Paul. Although Paul expressed how his (mostly gentile) congregants were 'washed ... rendered holy' by their baptism and faith in Jesus, impurity was definitely not a 'thing of the past' for Paul but remained a key concern in his letters (Ehrensperger 2016: I 88-9).

Admittedly, Paul's genuine and staunch concern for purity was not a particularly Jewish notion in ancient societies, yet other associations in the pagan world would never demand any kind of everyday ongoing state of purity by their members. Paul's worries fit better within Jewish traditions and a (Ehrensperger 2016: I9I). The same goes for his ideas about women members of his congregations: Tal Ilan argues that Paul's attitudes can best be ascribed to Pharisaic norms, rather than to Hellenistic or other influences (Ilan 2003: 94-8). Such norms also have corresponding patterns within Jewish synagogue environments in the diaspora. Women could learn scripture in the synagogue; they sang in the choir; they could prophecy and lead people in prayer (Ehrensperger 2015: 25 on 4 , $25 \mathrm{I}-3,258)$. What some scholars have perceived as more equal and liberal in Paul's attitudes towards women might thus actually be ascribed to Jewish traditions rather than to his stepping away from them (ibid. 254). Whatever Paul meant with his seemingly negative Torahpassages, it was hardly tantamount to 'no commandments', or to some sort of ethics without Torah-basis. The logic to his prescriptions is Torah-shaped.

\section{Paul was a flexible teacher when meeting gentiles}

A text often referred to in traditional interpretation as a support that Paul neglected Torah is I Cor. 9:19-23, where Paul is believed to reveal 
his halakhically care-free stance, being all things to all people. But Nanos (2013: 598) has argued that this kind of self-description - being a Jew to the Jews etc. - actually fits a rhetorical paradigm where Paul adjusted his argumentative strategy (not his lifestyle) depending on the listener. As exemplified in Acts I7, Paul tried to shape his gospel proclamation in a way that made sense to the particular culture where he was sharing his message. This did not necessitate any breaking of the Torah commandments.

Another possibility, suggested by David Rudolph in his book A Jew to the Jews (201 I), is that in I Cor. 9, Paul, very much like Jesus amongst Palestinian Jews, describes his missionary practice of visiting the household of anyone willing to receive the gospel message, be they 'sinners' or not. Paul's accommodations were thus in the realm of potential dinner company, not in the breaking of the Torah. It was showing this kind of friendliness and sharing the gospel with people that most probably constituted Paul's understanding of the 'Torah of the Messiah' (Rudolph 20I I: 20I-8).

When assessing such alternative approaches to understanding Paul, there is one flaw within the traditional perspective that needs particular mention: scholars who argue that Paul violated the Torah often display an understanding of the Torah which is very harsh, one-sided and - to put it frankly - un-Jewish. They seem to lack the up-to-date modern scholarly understanding of Second Temple Torah-observance as a diverse phenomenon. Karin Hedner Zetterholm (2015) argues that scholars must let go of essentialist understandings of what Torah observance might have meant for Jews in Paul's days. Whether a certain action was in violation of the Torah depended on the views of a particular group or person. We know, for example, that rabbinic, Qumranic and New Testament texts express differing opinions on how the Sabbath should best be kept. Rabbinic texts offer us insights into how commandments could be favourably interpreted in order to protect certain overarching principles of faith: the rabbis interpreted the commandment about an eye for an eye to mean monetary compensation rather than a verbatim application, and they circumscribed the law of executing a rebellious son with so many restrictions as to be virtually impossible to apply. 
They did so because both these laws on a literal level collided with their understanding of moral behaviour and their understanding of God as a compassionate and forgiving God. The Torah's ethical prescriptions and the existential understanding of God thus went 'hand in hand' when the Torah was applied to everyday situations (Hedner Zetterholm 201 5: 80-4). This attitude further resulted in the following flexibilities (ibid. 84-90, 94-7, ror):

- 'To act for the Lord' was the term used by the rabbis for suspending (rather than just beneficially interpreting) a certain law in a context where, for the moment, it was deemed to compromise the moral principles of the Torah as a whole;

- Sometimes two particular commandments collided in the sense that when one of them was performed, the other commandment was violated (for example when the priests officiated in the temple on the Sabbath). This created a situation where a person must prioritise and choose between the two commandments. Yet such a violation of the one commandment would not have been seen as violating the Torah as a whole - on the contrary, such a person would have been upholding and living out the Torah.

- The rabbis also adhered to the principle of mar'it 'ain, which meant that one must refrain from doing something which was actually permitted, if doing this might have given another Jew the impression that something forbidden was all of a sudden allowed, and hence caused that person to violate the Torah. Paul might be referring to a similar principle in I Cor. Io, where he wants to discourage behaviour in his congregations that might mistakenly be perceived by new believers as a permission to worship other gods apart from Israel's God - it is the intention or conscience of others which is at stake.

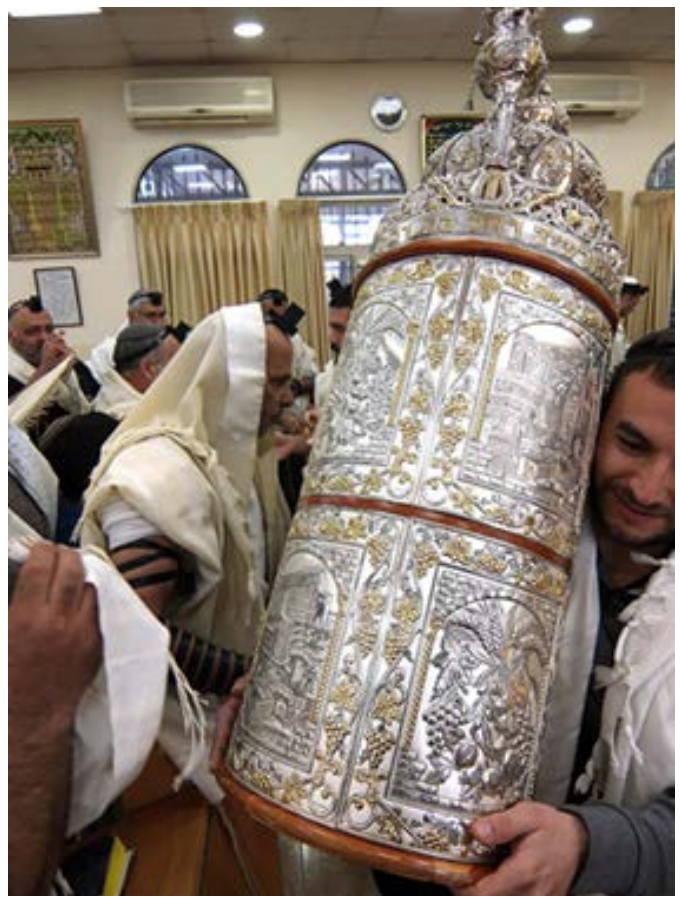

Taking out the Torah from the ark, en route to reading dais. Photo by Davidbena, 2018. CC-BY-SA 4.0. Wikimedia Commons.

One thus had to take into consideration not only the actual performance of a commandment, but also the effect it might have on other onlookers.

New Testament scholars often overemphasise a strict understanding of 'keeping the whole Torah', a concept which both Paul (Gal. 5:3) and the rabbis used, but in reference to the honest intent of being committed to the whole Torah, not of keeping every single commandment all the time. Jewish law was a much more flexible system than Christian scholars have traditionally maintained. Therefore we have no way of telling whether or not other Jews, or Paul himself for that matter, found Paul's halakhah lenient or strict - but Hedner Zetterholm's research makes it more difficult to claim that Paul consciously abandoned Torah (Hedner Zetterholm 2015: 85, IO3). 


\section{The Pauline syllogism}

Finally, the Jewish scholar and messianic rabbi Mark Kinzer in his book Post-Missionary Messianic Judaism (2005) asserts that there are some verses in Paul's letters which, when combined, effectively end the discussion about Paul's Torah observance, given the combination of facts that we derive from them. Kinzer uses what he calls the Pauline syllogism to argue that Paul himself indeed remained visibly Torah-observant, and also urged other Jesus-believing Jews to follow suit. Kinzer combines I Cor. 7:17-20, Gal. 5:3 and Gal. 5:I I in drawing this conclusion (ibid. $7 \mathrm{I}-4)$. In the first two texts Paul states that all who are circumcised should remain so, and that such persons are obliged to keep the whole Torah. 5 These statements would not have been trustworthy for the readers, had Paul himself deviated from these principles and not kept the Torah himself. The third text, the accusation against Paul that he still preached circumcision, is explained by Kinzer as the logical outcome of the two previous verses: Paul was not categorically against circumcision (for example, of Jewish children), but only as pertaining to gentiles. Had he also allowed gentiles to be circumcised, then the 'offence of the cross' would have been removed, as Paul wrote. Kinzer's point is that only this dual policy with Paul could have allowed for misunderstandings or false rumours about his views (Kinzer 2005: 72-3). The fact that Paul was so concerned about whether or not gentiles became circumcised indicates that his statements about circumcision being 'nothing' (Gal. 5:6 and I Cor. 7:1 9-20) should not be construed as meaning 'at all', but rather in relation to salvation, to entering the kingdom of God. That he wanted to protect circumcision, and Jewish Torah observance, shows his deep respect for the Jewish identity (Hayes 201 5: I 60-I).

5 Which, as Nanos points out, is rather a concern more than a 'threat' - no-one should do Torah half-heartedly (see Nanos 2002: 253).

\section{The benefits of Pauline studies within Jewish studies}

As this article indicates, and particularly the previous nine sections, there is an obvious logic to why the two obstacles for seeing Paul with new eyes - Christian tradition and terminologyseem to be less problematic when models, terms and concepts from Jewish studies are applied. These obstacles simply do not exist there. But of course Jewish studies have their own set of traditions and terminology, with their own inherent problems. I am not suggesting that the one is better than the other, or that the one should replace the other: they should rather join forces. So many new angles and interpretations on Paul and his letters come from modern Jewish scholars and thinkers: Paul makes sense within a Jewish matrix. Advances have been made with the help of studies in Apocalyptic Jewish texts, the Hebrew Bible, Qumranic texts, Mishnaic and Talmudic discourses, sociological studies on gender in Jewish cultures of antiquity, linguistics of biblical and Mishnaic Hebrew and Aramaic, Israeli archaeology, and much more. Without the research in things deemed Jewish, Paul would have remained the same. Pauline studies need Jewish studies.

But we can also turn things around, and look at it from the opposite perspective: seeing the Jewishness of Paul has contributed to our understanding of ancient Judaism(s), 6 regarding, for example, hic discussions between various Jewish groups, the position of women in Jewish culture, early forms of Merkabah mysticism, diaspora Judaism(s), views on gentiles and messianic expectations. The benefits have thus been mutual, because applying tools of historical-critical methods through a 'Jewish' lens redeems not only Paul but also Second Temple Judaism at large from shackles on both sides of the fence, as it were.

6 As duly noted by Alan Segal ( I 990: xiv-xvi). 
This is why I want, finally, to make a plea to universities in the Northern countries, and in Sweden in particular, to take up the discipline of Pauline research within Jewish studies. It is proper and timely to make a 'reversed cultural appropriation' by allowing Paul to return to the late Second Temple Palestinian and Diaspora Judaism(s) where he belonged. Contrary to the conclusion most easily drawn from glancing at the shelves of literature on Paul in a theological library, we still have so much to learn.

\section{Stefan Larsson is a student} at the Religious Roots of Europe master programme at Lund University, and a teacher of history and religions. He is currently writing a thesis on Galatians 3:1014 , and how this pinnacle of Paul's so-called law-free Gospel is recently being reinterpreted to fit with a Jewish, Torah-observant Paul.

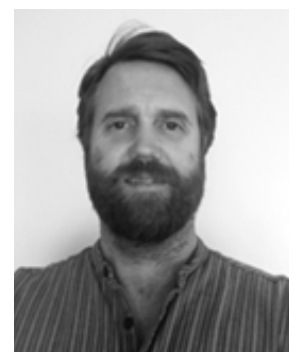

\section{References}

Ehrensperger, Kathy, 20I 5. 'The question(s) of gender: relocating Paul in relation to Judaism', Paul within Judaism: Restoring the FirstCentury Context to the Apostle, ed. Mark D. Nanos and Magnus Zetterholm (Minneapolis, Fortress Press), pp. 245-76

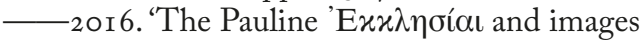
of community in Enoch traditions', Paul the Jew: Rereading the Apostle as a Figure of Second Temple Judaism, ed. Gabriele Boccaccini and Carlos A. Segovia (Minneapolis, Fortress Press), pp. I 83-2 I6

Eisenbaum, Pamela, 2000. 'Is Paul the father of misogyny and antisemitism?', Cross Currents, 5o(4), pp. 506-24

2009. Paul was Not a Christian (New York, Harper One)

Fredriksen, Paula, I 991. 'Judaism, the circumcision of gentiles, and apocalyptic hope: another look at Galatians I and 2', Journal of Theological Studies, ns 42(2), pp. 532-64

-2015. 'The question of worship: gods, pagans, and the redemption of Israel', Paul within Judaism: Restoring the First Century
Context to the Apostle, ed. Mark D. Nanos and Magnus Zetterholm (Minneapolis, Fortress Press), pp. I75-202

20I 7. Paul: The Pagans' Apostle (New Haven, Yale University Press)

Gager, John, 2000. Reinventing Paul (Oxford University Press)

Gaston, Lloyd, I 987. Paul and the Torah (Eugene, Wipf \& Stock Publishers)

Hayes, Christine, 201 5. What's Divine about Divine Law? (Princeton University Press)

Hedner Zetterholm, Karin, 20 I 5 'The question of assumptions: Torah observance in the first century', Paul within Judaism: Restoring the First-Century Context to the Apostle, ed. Mark D. Nanos and Magnus Zetterholm (Minneapolis, Fortress Press), pp. 79-104 Ilan, Tal, 2003. 'Paul and Pharisee women', On the Cutting Edge: The Study of Women in Biblical Worlds. Essays in Honor of Elisabeth Schüssler Fiorenza, ed. J. Schaberg, A. Bach, and E. Fuchs (New York, Continuum), pp. 82-Io I Johnson Hodge, Caroline, 2007. If Sons, then Heirs (Oxford University Press)

2015. 'The question of identity: gentiles as gentiles - but also not - in Pauline communities', Paul within Judaism: Restoring the First Century Context to the Apostle, ed. Mark D. Nanos and Magnus Zetterholm (Minneapolis, Fortress Press), pp. I 53-74

Kahn, Yoehl, 20 I I. The Three Blessings: Boundaries, Censorship, and Identity in Jewish Liturgy (Oxford University Press)

Kinzer, Mark, 2005. Post-Missionary Messianic Judaism: Redefining Christian Engagement with the Jewish People (Grand Rapids, Brazos Press)

Langton, Daniel R., 2010. The Apostle Paul in the Jerwish Imagination (Cambridge University Press)

Mason, Steve, 2007. 'Jews, Judeans, Judaizing, Judaism: problems of categorization in ancient history', Journal for the Study of Judaism, $38(4 / 5)$, pp. $457-5$ I 2

Nanos, Mark D., I 996. The Mystery of Romans (Minneapolis, Fortress Press)

2002. The Irony of Galatians: Paul's Letter in First Century Context (Minneapolis, Fortress Press)

2008. "Rethinking the "Paul and Judaism" paradigm: why not "Paul's Judaism"?', $<$ http://www.marknanos.com/ Paul\%27sJudaism-5-28-08.pdf> (accessed 4.8.2018) 
_ 2o го. "Callused”, not "hardened": Paul's revelation of temporary protection until all Israel can be healed', <http://www.marknanos. com/Callused-CentralSBL-5-6-ro.pdf > (accessed 4.8.2018)

-2013. 'Was Paul a "liar" for the Gospel? The case for a new interpretation of Paul's "becoming everything to everyone" in I Cor 9:19-23', Review and Expositor, I I o, pp. $59 \mathrm{I}-608$

-2015. 'The question of conceptualization: qualifying Paul's position on circumcision in dialogue with Josephus's advisors to King Izates', Paul within Judaism: Restoring the First Century Context to the Apostle, ed. Mark D.

Nanos and Magnus Zetterholm (Minneapolis, Fortress Press), pp. 105-52

Nanos, Mark D. and Magnus Zetterholm (eds.), 2015. Paul within Judaism: Restoring the FirstCentury Context to the Apostle (Minneapolis, Fortress Press)

Rudolph, David, 20 I I. A Jew to the Jerws: Jewish Contours of Pauline Flexibility in 1 Corinthians 90:19-23 (Tübingen, Mohr Siebeck)

Runesson, Anders, 2015 . 'The question of terminology: the architecture of contemporary discussions on Paul', Paul within Judaism: Restoring the First-Century Context to the Apostle, ed. Mark D. Nanos and Magnus Zetterholm (Minneapolis, Fortress Press), pp. $53-78$

Sanders, E. P., I 977. Paul and Palestinian Judaism (Philadelphia, Fortress Press)

Segal, Alan F., I 990. Paul the Convert (New Haven, Yale University Press)

Stendahl, Krister, I 976. Paul Among Jerws and Gentiles (Philadelphia, Fortress Press)

Stowers, Stanley K., I 994. A Rereading of Romans (New Haven, Yale University Press)

Thiessen, Matthew, 2016. Paul and the Gentile Problem (New York, Oxford University Press)

Zetterholm, Magnus 2003. The Formation of Christianity in Antioch (London, Routledge)

2009. Approaches to Paul (Minneapolis, Fortress Press)

-2015. 'Paul within Judaism: the state of the question', Paul within Judaism: Restoring the First-Century Context to the Apostle, ed. Mark D. Nanos and Magnus Zetterholm (Minneapolis, Fortress Press), pp. 3 I-52 